\title{
Cultures of the Lusophone Black Atlantic
}

\author{
Edited by
}

Nancy Priscilla Naro, Roger Sansi-Roca, and

David H. Treece 
Copyright $\mathcal{O}$ Nancy Priscilla Naro, Roger Sansi-Roca, and

David H. Treece, 2007.

All rights reserved. No part of this book may be used or reproduced in any manner whatsoever without written permission except in the case of brief quotations embodied in critical articles or reviews.

First published in 2007 by

PALGRAVE MACMILLANTM

175 Fifth Avenue, New York, N.Y. 10010 and

Houndmills, Basingstoke, Hampshire, England RG21 6XS

Companies and representatives throughout the world.

PALGRAVE MACMILLAN is the global academic imprint of the Palgrave Macmillan division of St. Martin's Press, LLC and of Palgrave Macmillan Ltd.

Macmillan ${ }^{\otimes}$ is a registered trademark in the United States, United Kingdom and other countries. Palgrave is a registered trademark in the European

Union and other countries.

ISBN-13: 978-0-230-60047-8

ISBN-10: 0-230-60047-6

Library of Congress Cataloging-in-Publication Data

Cultures of the lusophone Black Atlantic / edited by Nancy Priscilla Naro, Roger Sansi-Roca and David H. Treece.

p. $\mathrm{cm}$.

Includes bibliographical references and index.

ISBN 0-230-60047-6 (alk. paper)

1. Portuguese-speaking countries-Civilization-African influences.

2. Blacks-Portuguese-speaking countries-History. 3. Hybridity (Social sciences) I. Naro, Nancy Priscilla. II. Sansi-Roca, Roger. III. Treece, Dave.

DT594.C85 2007

305.896'017569-dc22

A catalogue record for this book is available from the British Library.

Design by Newgen Imaging Systems (P) Ltd., Chennai, India.

First edition: October 2007

$\begin{array}{llllllllll}10 & 9 & 8 & 7 & 6 & 5 & 4 & 3 & 2 & 1\end{array}$

Printed in the United States of America. 


\section{Contents}

Contributors

Introduction: The Atlantic, between Scylla and Charybdis Nancy Priscilla Naro, Roger Sansi-Roca, and David H. Treece

\section{Part I Colonial Formations}

Chapter 1

The Fetish in the Lusophone Atlantic

Roger Sansi-Roca

Chapter 2

Kriol without Creoles: Rethinking Guinea's

Afro-Atlantic Connections (Sixteenth to

Twentieth Centuries)

Philip J. Havik

Chapter 3

Historical Roots of Homosexuality in the Lusophone Atlantic Luiz Mott

\section{Part II Migrations and Colonial Cultures}

Chapter 4

Atlantic Microhistories: Mobility, Personal Ties, and

Slaving in the Black Atlantic World (Angola and Brazil)

Roquinaldo Ferreira

\section{Chapter 5}

Colonial Aspirations: Connecting Three Points of the Portuguese Black Atlantic

Nancy Priscilla Naro

Chapter 6

Agudás from Benin: “Brazilian” Identity as a

Bridge to Citizenship

Milton Guran 
vi

Chapter 7

Emigration and the Spatial Production of

Difference from Cape Verde

Kesha D. Fikes

Chapter 8

African and Brazilian Altars in Lisbon-Some Considerations on the Reconfigurations of the Portuguese Religious Field

Clara Saraiva

\section{Part III Hybridity, Multiculturalism, and Racial Politics}

Chapter 9

History and Memory in Capoeira Lyrics from Bahia, Brazil

Matthias Röbrig Assunção

Chapter 10

The "Orisha Religion" between Syncretism and

Re-Africanization

Stefania Capone

Chapter 11

Undoing Brazil: Hybridity versus Multiculturalism

Peter Fry

Index 


\title{
Chapter 9
}

\section{History and Memory in Capoeira Lyrics from Bahia, Brazil}

\author{
Matthias Röhrig Assunção
}

$\mathrm{O}$

ver the last years, British television has shown clips of capoeira almost daily. One of the "idents" used by the British Broadcasting Corporation to advertise multiethnic "Cool Britannia" features capoeira, and is usually broadcast at prime time just before the ten o'clock news. This is just one example of how globalized capoeira has become, and it also demonstrates how much young Brazilians from modest backgrounds and with no formal education can achieve through capoeira. Yet capoeira's very success also entails the danger that the art might become just another commodity marketed by global capitalism. Capoeira is not just a different type of aerobics or flashy acrobatics accompanied by exotic music. It is a multilayered art form of amazing cultural density, with its own worldview and a history closely linked to that of the African Diaspora. The lyrics are central to the capoeira game to stimulate players or to comment on their performance and are thus worth an analysis on their own.

Slaves and freed people widely practiced combat games in late colonial and imperial Brazil. Different modalities, known under the generic name capoeira, developed according to both the vicissitudes of the transatlantic and internal slave trades and the local contexts in Pará, Pernambuco, Bahia, Rio de Janeiro, and other regions. Capoeira usually involved some form of mock combat in a circle, the roda (ring), accompanied by instruments, hand clapping, and singing. Whilst friendly games were part of slave and popular diversions, rougher games could end in brawls, injuries, and even death.

Throughout the Brazilian Empire (1822-1889), authorities considered that playing capoeira was "unacceptable behavior" requiring immediate correction in the form of whipping and forced labor in the Navy dockyards. The Republican Penal Code (1890) outlawed it together with vagrancy. Repression of the capoeiras, ${ }^{1}$ although brutal, was often unsystematic and inefficient. ${ }^{2}$

Where and how did capoeira originate? This is a question twentieth-century practitioners often raised and still discuss with passion since capoeira is paramount to the construction of several identities. Since primary sources referring 
to capoeira or anything similar in Brazil only extend back to the early nineteenth century, adepts have advanced theories about its origins that suit their particular aspirations and world views. They therefore emphasize either the "Brazilian," or the "African" character of capoeira, and eventually tend to fabricate the appropriate foundational myths. ${ }^{3}$ The narratives of its origins intersect (though not entirely overlap) with discourses of purity versus miscegenation and these are also paramount to the definition of contemporary styles.

To simplify, we can distinguish three theories. Brazilian nationalists insist that capoeira was invented in the Portuguese colonies in America. Authors such as Burlamaqui suggested that runaway slaves, living close to nature in the distant backlands, were inspired by the movements of animals. He therefore concluded that capoeira originated entirely within the Brazil environment. ${ }^{4}$ In contrast, Afrocentric theories emphasize the importance of the slaves' original cultural backgrounds. One theory defends a single African origin of capoeira from the Kongo/Angola region (1928: 11-12). A third hypothesis suggests that in Brazil capoeira resulted from the amalgamation of different African combat traditions.

In my opinion, at the present state of knowledge on the subject, the last theory is the most convincing and consequently enjoys the most widespread support among the capoeira community. No early modern source documents the existence of any art in Africa that is similar to capoeira, even though there are specific formal similarities in some contemporary phenomena. Yet the coexistence of various combat games practiced by enslaved Africans in one location is clearly documented in Brazil. In Bahia, for instance, capoeira was practiced alongside batuque and maculêlê, and eventually incorporated and absorbed the latter two during the twentieth century. The existence of different styles within capoeira and the struggle over what movements should or should not be allowed also suggests that these might derive from different and conflicting martial traditions. Moreover, specific rhythms and associated types of games were often identified with a particular neo-African

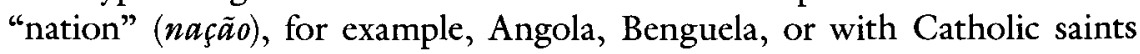
(São Bento, Santa Maria). The worship of saints, as practiced by lay brotherhoods, equally fulfilled the function of aggregating slaves and freed people from similar ethnic backgrounds in the Catholic colonies of the Americas. The coexistence of these different types of rhythms and games also suggests that-analogous to Candomblé-different African combat traditions came together in Brazilian capoeira.

In the particular case of Bahia, capoeira evolved further during the last decades of the nineteenth and the first decades of the twentieth century, especially among porters, stevedores, sailors, and fishermen in the port areas of Salvador and the towns of the adjacent sugar belt around the Bay of All Saints. "Vagrancy" (vadiação), as its adepts called it, was played in breaks during work or in popular neighborhoods on Sundays. It provided entertainment and relaxation from hard labor. Playing capoeira or "being idle" (padiar) became an integral part of a broader Afro-Bahian popular culture. Together with samba-de-roda and batuque it had a prominent place in the multicultural cycle of celebrations to honor Catholic saints and associated African divinities (from December to Carnival). At least by the end of the nineteenth century, capoeira had become a complex manifestation with elaborated rituals.

During the twentieth century, capoeira underwent a process of modernization. Paramount to this development were the "Regional" and "Angola" styles that developed in Bahia from 1930 onward. These styles were exported to other regions of Brazil, in particular to Rio de Janeiro and São Paulo, where they underwent further changes and fused into what is known as "contemporary capoeira." Since the 1980s, capoeira has experienced an impressive process of globalization and is now played across the five continents.

This chapter examines how capoeira lyrics tell the history of the Afro-Brazilian experience. In my analysis of some core themes-Africa, slavery and abolition, wars and famous fighters-I intend to show how capoeira maintains a complex and dynamic relation with the past that still provides inspiration and models for contemporary practice. As adepts and scholars have pointed out, the capoeira game reenacts the past, a "sinister" past of oppression and betrayal, but also one of resistance and playfulness (Downey 1998: 121).

\section{The Lyrics in the Game}

Even though capoeira could become a lethal weapon in street fights, everyday practice in Bahia took the form of a game in which it was more important to show the harm one could do to the other player rather than actually cause injury to an opponent. Adepts in Bahia explicitly referred to it as brincadeira, or jogo ("playing" or "game") and even today the performance in the capoeira roda (circle) is called a game. Capoeira took place in an imaginary roda that was formed by the orchestra (bateria) and the other participants or spectators. Two players knelt in front of each other and next to the orchestra at the "foot" of the berimbau (percussion instrument). They listened to preliminary chants until the lead singer intoned one standard phrase such as "turn around the world" ("volta ao mundo"). That was the signal for the game to begin. Players genuflected, drew signs on the ground, and started their game. Many capoeira groups today still comply with that basic structure.

We do not know what African slaves sang in the nineteenth century rodas, but they must have chanted in their own languages. Yet, unlike Candomblé, where secrecy and initiation are paramount, and where the core of religious chants are still based on African languages, more profane celebrations such as samba-de-roda, batuque, and capoeira aimed to reach and appeal to wider, multiethnic audiences. We can thus assume that capoeira songs creolized more rapidly, even though we still do not know how that process took place. It is possible that early capoeira songs in Portuguese were translations of original African songs. They may have merged verses from various languages and literary traditions from several cultures. Since no nineteenth century transcripts are known, it is difficult to make any definitive statement on the matter although a systematic comparison with African and European genres might shed more light on this issue. Antônio Risério, for instance, has 
highlighted the influence of Yoruba oriki on contemporary Brazilian writing and the lyrics of MPB (Popular Brazilian Music) (1995: 165-183). Waldeloir Rego has emphasized the influence of medieval Portuguese genres on capoeira lyrics (1968: 235, 240, 245).

Capoeira lyrics sung in twentieth century rodas touch on many themes. They articulate the everyday struggle for survival or reflect on human relationships and sentiments such as love and friendship, envy and competition. They fulfill a range of functions within the game and beyond it. In formal terms, four basic types of capoeira songs can be distinguished. The introductory "litany" (ladainha) consists of a monologue by the lead singer who is usually one of the more experienced players or a respected teacher (mestre). Since everyone is expected to pay particular attention at this time, the singer uses the moment to pass his personal message to the audience. This is followed by the "praise" (louvação, canto de entrada or chula), where the chorus repeats the verse of the lead singer. At this time, praise is offered to deceased mestres and then to living mestres or teachers who might be present ("Iê, long live my mestre"). The audience is then informed that the game is about to begin, or that the players are wicked or particularly good at using head butts (mandingueiro, cabegeiro). The praise can also be used to warn one player about the strengths of his opponent. When the lead singer starts a corridor (short verses that the audience answers with a refrain) the players begin their game.

These three types of song and their sequence are still part and parcel of many of the contemporary capoeira rodas that attempt to closely follow tradition. It is therefore difficult to assess to what extent earlier practices departed from this structure. Evidence does suggest that there was at least a fourth type of song, a quadra that was commonly executed in early-twentieth-century Bahian rodas. According to Greg Downey, the quadra is "a type of short solo that is followed by call and response and can be sung during play, unlike the solo ladainba which will stop play"(1998: 124). M. Bimba, among others, excelled in quadras and has recorded some of them. ${ }^{5}$ Finally, the cantiga de sotaque represented a variation or sub-type of the ladainba mode. Instead of one player, it consisted of two players who improvized verses alternatively to challenge each other. The cantigas de sotaque usually preceded a game between mestres or experienced players able to improvize. (Lewis 1992: 169-172) They thus resembled the verbal challenges (desafios) common in the popular culture of northeast Brazil.

As Lewis wrote, "the introductory ladainha/chula complex clearly establishes a ritual framework for the play to follow" (1992: 217). This ritual framework was maintained during the game in a number of ways. Many corridos that were sung during play continued to ask for spiritual protection or referred to a wider religious context. A roda was usually closed by a specific corrido ("Adeus, adeus"), announcing that the players were about to depart with the protection of God and Our Lady the Virgin Mary. Many corrido lyrics take the form of proverbs, which transmit an important insight: "Whoever can't cope with mandinga (witchcraft) should not carry an amulet" ("Quem não pode com mandinga, não carrega patuá"). ${ }^{6}$ Since lyrics frequently use metaphors or allusions, their meaning is never straightforward, but often ambiguous and multilayered. Mandinga, for instance, also refers to a particular twisted manner of moving in capoeira, which is considered an important asset for good style.

Capoeira lyrics also only acquire their full meaning in the context of the roda. The particular situation of the game often explains why the orchestra intones a specific corrido. For example, when a small player fells a bigger one, the lead singer might sing: "Baraúna caiu, quanto mais eu" (Baraúna [a huge tree] has fallen, even more so do I). When a player dislikes the jiu-jitsu-type grabbing used in some styles but frowned upon in others, he or the lead singer might start singing: "Ô Dona Alice não me pegue não" $(\mathrm{Oh}$, Dona Alice don't grab me). ${ }^{7}$ Capoeira lyrics can thus tell an episode from the past but at the same time use this episode to comment on the present.

Furthermore, the song will never provide a detailed account of an historical episode. It will only allude to some key moments of a story that the mestres or the older players previously made known to the audience in conversations that took place after the roda, the training sessions, or on other occasions. Songs therefore relate to broader narratives that have been transmitted in other ways and forms. The polysemy of terms and the ambiguity of a particular episode alluded to in a song allows adepts to play with meanings.

The lyrics entertain a complex relationship with the game as it develops in the roda. Songs induce players to "let out their mandinga," to play slowly using all their resources, or to play fast and aggressively. The songs exhort the players and the audience to respect and to follow the traditions of mestres who have long since died. The lyrics may also ironically comment on the actual game by drawing comparisons with the past or by improvising critical remarks that are directed toward the players in the roda. The possibility of using tradition to interpret the present and to improvise new verses that are adequate for any situation is seen by adepts as a key aspect of capoeira lyrics. It allows them to channel emotions and to control aggression within the framework of the roda. It places the actual performance within a broader, almost timeless sequence of games that stretches back to an immemorial past. And, finally, it allows practitioners to critically comment on distance themselves from events that are taking place inside and outside the roda. ${ }^{8}$

\section{History and Memory in Capoeira Lyrics}

Waldeloir Rego made it clear that no clean division is possible between the "old" and the "present day" capoeira songs. Many lyrics that are considered new are in fact based on very old songs, whereas songs called traditional sometimes have quite recent origins. He also pointed out the difficulty of distinguishing between capoeira songs proper and songs of other provenance (samba, Candomblé, etc.) that are used in a capoeira roda (1968: 89). The distinction between "traditional" and "new" songs is difficult because of the tension that exists between tradition and innovation in any roda performance. Corridos, for example combine a verse by the solo singer with a refrain by the 
chorus. Whilst the refrain is often traditional, experienced solo singers begin with a couple of traditional verses and then add their own verses or improvise them on the spot. The same happens in the praise songs, where the solo singer can add new verses to the traditional ones that are then repeated by the chorus.

When Rego published his classic account in 1968, he had witnessed the modernization of the art since the 1930s and thought it necessary to warn his readers against a simplistic distinction between traditional and new songs. The transformations of capoeira since its spread throughout Brazil in the 1960 s and, more recently into other countries were even more substantial than the changes that Rego observed. The following example illustrates the way songs are disseminated. Every capoeira group can now record its own $\mathrm{CD}$ and this constitutes a source of prestige and further income if other groups and the wider capoeira community adopt the new songs.

For historians, it is nevertheless important to try to distinguish the lyrics that were used at different moments of capoeira history. Since the beginning of the last century, for example, some ethnographers and folklorists have transcribed the lyrics that they collected on the spot. Manuel Querino, Edison Carneiro, Antônio Viana and some others have provided us with precious examples from the first decades of the twentieth century. In 1941, Lorenzo Dow Turner recorded capoeira songs from two Bahian mestres (Bimba and Cabeçinha).

The samples were, however, very limited and unsystematic. Rego's book, which contains over 150 capoeira lyrics that he registered from many different mestres, represents the first systematic attempt at compilation. The texts he collected reflect what was being sung in Salvador during the 1950s and 1960 s. His compilation already contains some important innovations that relate to the emergence of the two modern Regional and Angola styles. I believe, however, that these songs are still relatively traditional when compared to the impressive quantity of new songs that have been composed, performed, and recorded over the last forty years. Together with the songs performed by the "old guard" of Bahian mestres such as Waldemar, Traíra, Canjiquinha, Caiçara, Pastinha, Bimba, João Pequeno, João Grande, Paulo dos Anjos, and others (recorded during the 1960s or later) they constitute a corpus that can be considered traditional in opposition to the many and entirely new capoeira songs.

It is nevertheless important to emphasize that traditional does not mean unaltered. In the case of the ladainhas, a set number of verses of different length are recognized as coming from the public domain. Many mestres combine them in their own, original way, often adding or inserting some verses of their own composition. In the case of the lowvaf̧a a, a set of wellknown praises from the public domain is often followed by a number of new ones that closely follow the established model. The traditional corridos start with a basic refrain and some well-known solo verses from the public domain. Every performer may or may not add some new solo verses that still use the traditional refrain. Each performance can therefore consist of an original combination of traditional elements and the eventual addition of new or more recent verses. In other words, although the core of the older lyrics can be considered traditional, their performance always allows for innovation. This dynamic has led to the existence of many different versions of one ladainba or the recurrent use of the same verses in different capoeira songs.

Once we recognize the importance of creative bricolage through which traditional songs are complemented and enriched by new additions and interpretations, it is difficult to maintain a strict separation between old and new. Instead of attempting to neatly separate traditional and recent lyrics, it is better to distinguish those from the public domain from entirely new songs by a known composer. ${ }^{9}$ The core structure of these songs from the public domain may be very ancient but this does not exclude recent additions. Unfortunately, it is only sometimes possible to document older versions and in any case, we cannot track them farther back than the first decades of the twentieth century. With regards to the new songs, some mestres of the Angola style, such as $M$. João Pequeno, João Grande, Boca Rica, Paulo dos Anjos, Moraes, or Roberval create entirely new songs that remain within the parameters of tradition, although what exactly tradition entails can still be the subject of heated debates. Composers who represent other contemporary styles take much greater liberties so that some recent capoeira lyrics and songs have a greater resemblance to contemporary Brazilian funk or rap.

Since capoeira lyrics thematize human relations in specific historical contexts, they can be considered, at least in the broadest sense, to constitute an historical source. Yet, many songs also have a universalizing message about human behavior that evades historical examination. I will therefore concentrate on four themes that seem to me particularly suited to the analysis of the relationship that practitioners have with history and memory: Africa, slavery and abolition, wars involving Brazilians, and famous capoeira fighters. For reasons of space I will limit my discussion to the lyrics, and exclude the narratives that mestres told before or after the rodas, during classes or during other events.

\section{Africa in Capoeira Lyrics}

There can be no doubt that Brazilian capoeira is linked in many ways to the cultures of the enslaved Africans. Capoeira in Rio de Janeiro and Bahia has been repeatedly associated with the Angolas and Benguelas, the slaves deported from Western Central Africa. ${ }^{10}$ The origin of the berimbau, the "soul" and main symbol of the art, is the musical bow that many ethnic groups in the Angola/Kongo region use. On the other hand, the berimbau does not appear to have been used for any martial art in Africa and the instrument is played today with a caxixi that scholars have traced to the Bay of Benin. The composition of the capoeira orchestra is clearly a New World reinvention that combines instruments from various cultures, including the Arab pandeiro (tambourine). ${ }^{11}$ 
Whilst swift change characterized instruments, audiences, and texts in capoeira, the rhythmic patterns seemed to have remained more stable. Ethnomusicologists insist that in contrast to instruments that were used across various culture zones, rhythmic patterns marked more specific regional identities (Kazadi wa Makuna 2000: 132). G. Kubik has called time-line patterns "the metric back-bone" of African music. "They are orientation patterns, steering and holding together the motional process with participating musicians and dancers depending on them. In this quality the removal or even slight modification of a time-line pattern immediately leads to the disintegration of the music concerned" (Kubik 1979: 18) He asserts that these rhythmic key signatures enjoyed great constancy over time. Thus a twelvepulse pattern in its seven-stroke version played on a bell can be identified as a West African Coastal tradition (Akan/Fon/Yoruba) or a sixteen-pulse pattern as coming from the Kongo/Angola region (Kubik 1979: 124-127).

It is much more difficult to establish transatlantic links regarding the movements, the rituals, and what some adepts call the spirituality of capoeira. In my view, any debate over these issues should take into account the lyrics. ${ }^{12}$ The texts of capoeira songs are always in vernacular language and, in particular, those from Bahia are greatly influenced by the speech of African slaves and their descendants. No creole language developed on a large scale in the Portuguese colonies in America ${ }^{13}$ but even in its mainstream version Brazilian Portuguese has retained important influences of African, mainly Bantu languages. Bahian Portuguese, in particular, is shaped by the way Africans pronounced it. Rego has shown with painstaking detail how words are systematically altered; for instance, the 1 substitutes the $r$ or is dropped from the end of words. ${ }^{14}$

Furthermore, many African terms have entered colloquial Brazilian speech and are used in capoeira lyrics. For example, muleque-a boy in Kimbundohas acquired the slightly altered meaning of a street kid in Brazil. Thus the song "The muleque is you" ("Muleque é tu") provocatively states that one's opponent - to whom the song is addressed-is a badly behaved street kid.

Despite the many formal and ritual aspects that link capoeira practice to Africa in general, and to the Kongo/Angola region in particular, relatively few songs from the public domain contain explicit references to things African. One frequently used term is "Aruandê" (or "Aluandê," "Aloanguê"). It is sometimes employed in association with the interjection lê!, which is a call for attention, and also the ritual way to start or finish a roda, or to introduce the louvação (praise song). There seems to be no doubt that the term is derived from Luanda, the capital of Portuguese Angola, an important port in the transatlantic slave trade to Brazil (Rego 1968: 49, 93, 145, 184). Capoeira lyrics also use a number of expressions of likely African origin, such as jacatimba, camunjerê, or calum$b i{ }^{15}$ They might or might not be onomatopoeic but for many of these terms no meaning is known among contemporary adepts.

One reason for the relatively limited references to Africa is the repression of capoeira and any African cultural manifestation prior to the 1930s. This led to dissimulation and deception. In the case of Afro-Bahian religion, it is possible to identify hidden references. For example, a corrido which mentions dendê (palm oil) can also refer to spiritual energy or the messenger deity Exú. ${ }^{16}$ Many songs worship Catholic saints such as Santo Antonio, São Benedito, and São Bento. It is well known that slaves chose devotion to particular saints to hide their worship of African Gods to the extent that Candomble practitioners in Bahia called themselves "the people of the Saints."

I believe that references to Africa might have been more frequent in nineteenth-century lyrics but disappeared after the end of the transatlantic slave trade due to the growing distance between capoeira practitioners and Angolan origins. Although Bahia continued to maintain a number of important links with the Bay of Benin after 1850, it seems that this was less true of Angola. For instance, the corrido "Ô lembá, ê lembá. Ê lembá do Barro Vermelho" ("Oh lembá, eh lembá, eh lembá of red clay"). ${ }^{17}$ Lemba is a small place in Angola, but also, and more importantly, a feminine spirit associated with procreation, and the birth of twins. Lemba furthermore became the denomination for a specific cult that existed in the Kongo region between 1650 and 1930. Lemba has also been identified in the diaspora, for example as a $l w a$ in Haitian Vodou (of the Kongo or "Petro" line) (Ribas 1994: 2, 144; MacGaffey in Heywood, ed. 2002: 214, 223). ${ }^{18}$ However, very few contemporary mestres associate that capoeira song with a specific religious meaning. Lembá is often altered to "lembra" (= remember in Portuguese) and new verses are added that relate to the act of remembering. In other words, in this particular case the original African referent has been lost.

It is possible, on the one hand, to observe the loss of certain African references in twentieth-century capoeira. On the other hand, contemporary capoeira lyrics, and in particular those of the revivalist Angola style, have systematically reintroduced links to Angola. Traditionalists who aimed to preserve capoeira refused its modernization along the lines of M. Bimba's Regional style in the 1930-1940s. Angola was chosen as their rallying concept, based on the historic association of the art with the Angolan slaves. Hence adepts of the Angola style dubbed themselves angoleiros, ${ }^{19}$ and invented refrains such as "Angola-E" or "Eu sou angoleiro/Angoleiro sim senhor/Angoleiro de valor" ("I am angoleiro/an angoleiro yes Sir/An angoleiro of value"). ${ }^{20}$

When the Angolan artist Souza e Neves visited Pastinha in Salvador in 1965 , he must have told the old mestre his theory regarding the single origin of capoeira in southern Angola. M. Pastinha thus added the verse "Capoeira came from África" to his Ladainba "Bahia, Our Bahia."2l Yet after he went to the Festival des Arts Nègres (First World Festival of Black Arts) in Dakar, in 1966, he also proudly sang: "Pastinha has been to Africa, to show capoeira from Brazil." 22 In other words, older mestres did not necessarily see Afrocentric approaches and one's pride in being Brazilian as mutually exclusive.

The reestablishment of links with Africa or the re-Africanization (a term commonly used for analyzing similar trends in Afro-Brazilian religions) includes a recovery of African locations. M. João Grande, a 
disciple of Pastinha who moved from Salvador to New York during the 1990s, sings:
Saí do Congo
Passei por Angola
Cheguei aqui hoje
Quero vadiar Angola
I left Congo
I passed by Angola
I arrived here today
I want to play ["be idle"] Angola ${ }^{23}$

His disciple M. Moraes has created lyrics that provide a careful definition of Angola as opposed to mainstream capoeira styles:
Tudo é diferente, na Angola (Refr.)

A viola responde, na Angola

A pergunta é do gunga, na Angola

Berimbau afinado, na Angola

O jogo é de baixo, na Angola
Na Angola, na Angola

Jogo de Mandinga, na Angola
In [the] Angola [style], in Angola Everything is different, in Angola The game is mandigueiro, in Angola The piola answers, in Angola

The question comes from the gunga, in Angola

The berimbau is tuned, in Angola

The game is low, in Angola ${ }^{24}$
This mestre's belief in the need to reaffirm the African character of capoeira has lead him to study Bantu languages and compose new songs that intermingle Bakongo and Portuguese terms in similar fashion to the uses by adepts in the old days of the vadiação:

$\begin{array}{ll}\text { Ngolo, Nguzu } & \text { Ngolo, Nguzu } \\ \text { Força e poder } & \text { Strength and power } \\ \text { Kiatálua não } & \text { [Envy?] } \\ \text { Vai me vencer } & \text { Will not kill me }{ }^{25}\end{array}$

For the period for which we have evidence, these few examples illustrate the extent to which the role of Africa in capoeira lyrics has undergone major changes.

\section{Slavery and Abolition}

It is possible that many capoeira lyrics originated during slavery although only a few songs from the public domain make explicit references to the institution and to the relation between slaves and masters. The most famous one is:
Vou dizer a meu senhor Que a manteiga derramou
A manteiga não é minha
I am going to tell my master That the butter has spilled
The butter is not mine
The butter belongs to the master (PD)

This song conveys the malice of the slave. He relates an accident but at the same time one feels that he is gloating over what happened because he stresses that the butter does not belong to him, but to the master.
The covert resistance of the slave coalesced into malandragem, malice that has since become a strategy of survival of the urban poor. It is not surprising that malandro (rogue, spiv) and capoeira became synonyms around the turn of the nineteenth century. The cunning of the malandro is alluded to in a number of capoeira songs.

Slavery and its abolition are still themes of recent capoeira songs. The thirteenth of May, the day of slave emancipation in 1888 became a day of festive celebration in the aftermath of abolition. For example, capoeira was prominently played in Santo Amaro in the sugar plantation belt in the market square alongside maculêlê (stick fighting dance) and Candomblé. In his ladainha performed in the 1980s, the Bahian mestre Canjiquinha was among many others in his praise of the princess Isabel who signed the "Golden Law":

\author{
Salve! Salve a nação \\ Salve a nação brasileira \\ Salve Princesa Isabel, ô meu Deus \\ Que me livrou de cativeiro
}

Hail! Hail the nation

Hail the Brazilian nation

Hail Princesa Isabel, oh my God

Who delivered me from captivity!

(M. Canjiquinha) $^{26}$
The abolition of slavery underwent a major reassessment during the celebrations of the Centenary in 1988. Black consciousness groups (usually referred to as Movimento Negro) pointed out that black people in Brazil had nothing to celebrate. They opted for the date of the death of the maroon leader Zumbi to commemorate black resistance. Accordingly, the views of many capoeiristas on Abolition changed considerably and references to marronage became common:

\author{
Dona Isabel, que história é essa \\ De ter feito abolição? \\ De ser princesa boazinha \\ Que acabou com a escravidão? \\ Estou cansado de conversa \\ Estou cansado de ilusão \\ Viva Zumbi, nosso guerreiro \\ Que fez-se herói lá em Palmares \\ Viva a cultura desse povo \\ A liberdade verdadeira \\ Que já corria nos quilombos \\ Que já jogava capoeira
}

\author{
Lady Isabel, what story is this \\ That you made abolition? \\ That you are the nice princess \\ That finished with slavery? \\ I am tired of that idle chat \\ I am tired of that illusion \\ Long live Zumbi, our warrior \\ Who became a hero in Palmares \\ Long live the culture of this people \\ The true freedom \\ Already existed in maroon \\ settlements \\ Already played capoeira
}

Slavery and its abolition are not the only explicit historical references used in capoeira lyrics. The "classic" form of Bahian capoeira developed during the second half of the nineteenth and the first half of the twentieth century. Capoeira lyrics from this time referred to Brazil's important steps in nation building and to its participation in two international wars. 


\section{The Wars Brazilian Capoeiras Fought}

Since the seventeenth century, Brazilian masters and colonial authorities used the martial skills of their slaves in times of need. Black troops or Henriques (named after Henrique Dias (?-1662) the famous commander of a black battalion in the wars against the Dutch in northeastern Brazil) offered one possible path to emancipation. During the Paraguayan War (1865-1870) when the National Guard and voluntary battalions had to reinforce the relatively reduced Brazilian army, there was a renewed offer of freedom for slave volunteers. The province of Bahia sent hundreds of Brazilian-born slaves as well as thousands of free blacks the 15,000 soldiers to Paraguay. The surviving slave veterans were subsequently freed for serving the fatherland. ${ }^{28}$ Manuel Querino stated that the capoeira soldiers distinguished themselves in bayonet assaults and presented profiles of two of them (1946: 78-80). ${ }^{29}$

The Paraguayan War resulted in unprecedented patriotic mobilization, a growing awareness of belonging to a Brazilian nation that profoundly altered Brazilian civic culture. In the capital of Bahia the war was behind popular manifestations such as the "pilgrimage of the police" which celebrated the return of the police corps from the battlefields (Querino: 244). Streets and squares of Salvador and other cities were christened with the names of famous battles in which the Brazilian armed forces were victorious.

Given the participation of capoeiras in the wider context of an international war, it is no surprise that places and events associated with the Paraguayan War, such as "Humaitá," "City of Assunción" and possibly "Paranaê," are among some of the oldest identifiable references in capoeira songs. ${ }^{30}$ The song "I was at home" tells the story of how one man was recruited:

Iê, tava em casa (ô meu bem)

Sem pensar nem imaginar

Quando bateram na porta (meu bem) Salomão mandou chamar

Para ajudar a vencer (ô meu bem)

A Guerra do Paraguá (DP)
Iê, I was at home (oh my love) not thinking nor imagining anything

when someone knocked on the door Solomon asked for him

To help win (oh my love)

The War of Paraguay (PD) ${ }^{31}$

During the Second World War Brazil sent an expedition corps to Italy to fight under United States command against Nazi Germany. The ladainha "Brazil said yes, Japan said no" is still sung in contemporary rodas and invokes the participation of an anonymous capoeira in that conflict:

O Brasil disse que sim O Japão disse que não Uma esquadra poderosa Pra brigar com alemão (DP)
Brazil said yes Japan said no A powerful fleet

To have a fight with the German $(P D)^{32}$
The ladainba often includes a passage that clearly expresses the patriotic sentiments of the capoeira fighting for his country:
Meu dever é ir lutar (DP)
O Brasil já tá na guerra
Brazil is at war

My duty is to fight (PD) ${ }^{33}$
Since the end of the nineteenth century, nationalist intellectuals and politicians have sought to instrumentalize capoeira for their own purposes. During Brazil's major surge of nationalism from the 1930s to the 1950s, capoeira the dictatorship of Getulio Vargas. Capoeira was decriminalized during reelected president (1950-1954), Vargas, who was later and endorsed capoeira as the national atted an official capoeira exhibition between capoeira and artial Complex links today many capoeira adepts use the politics were thus established and even uniforms.

\section{Famous Capoeira Fighters}

"Tough guys" who confront local police or armed groups that outnumber them are more admired in capoeira lyrics from the public domain than the Brazilian soldiers who fought abroad. The two outstanding examples are Besouro Mangangá and Pedro Mineiro.

A number of capoeira songs recall the death in 1914 of Pedro Mineiro inside a police station. ${ }^{34}$ This famous troublemaker may have been a pimp in the port area and its red-light district where he had his base. He was prosecuted several times and owed his own violent death to disputes such as his violence against women and fights with other men over women. According to $M$. Noronha, he was the lover of the waitress Maria José who went out one day with a sailor Pedro Mineiro followed them, killed one marine, and threw another one from a window. He was arrested and detained at the police station. The captain of the sailor's ship was dissatisfied with the arrest since it was known that the police chief, Alvaro Cova, was a known protector of capoeiras. ${ }^{35}$ The captain's men therefore invaded the police station to kill Pedro Mineiro. One ladainba tells the story as follows: "The Warship Piauí, anchored in the port of Bahia. An insubordinate sailor jumped off to create mayhem. They ordered Pedro Mineiro to be inde! comrade! 36

A number of different versions of this ladainha are sung in rodas, all emphasizing the death of Pedro Mineiro inside the police station:
Prenderam Pedro Mineiro

Dentro da Secretaria

Para dar depoimento

Daquilo que não sabia(DP)
They arrested Pedro Mineiro Inside the police station To give testimony About what [something] he did not know $(\mathrm{PD})^{37}$ 
The episode of Pedro Mineiro reveals several important facets that help to explain the links between capoeira and violence: the use of its techniques to subject women, the rivalry between different corporate bodies such as the navy and the police, and the involvement of capoeiras in clientelism. The records in the archives do not always reveal the complex web of wider social significance that lie behind the individual fights and their immediate motives. ${ }^{38}$

\section{Innovation and Tradition in Capoeira Lyrics}

Tradition is handed down in capoeira through song lyrics and the rituals of the game. Yet tradition is never static or rigid. With regard to lyrics, each new generation of capoeira practitioners recombine textual elements into something original and also something new that is still within the boundaries of tradition. Every performer thus adds to the script of tradition: by deleting some components and introducing new ones, he (since almost all are men) produces some change in the texture without fundamentally altering the structure.

The ladainba sung by M. Caiçara (1923-1997) might serve as an example of how capoeira mestres adapted and merged traditional elements into a new song:

$\begin{array}{ll}\text { Iê! } & \text { Iê! (Attention!) } \\ \text { Iê tava em casa } & \text { I was in my home } \\ \text { Sem pensar nem imaginar } & \text { Without thinking nor imagining } \\ \text { Delegado no momento } & \text { The police chief } \\ \text { Já mandou foi me intimar } & \text { Sent me a warning } \\ \text { É verdade meu colega } & \text { Is it true my friend } \\ \text { Com toda diplomacia } & \text { With all diplomacy } \\ \text { Prenderam o capoeira/Caiçara } & \text { They put the capoeira/caiçara } \\ \text { Dentro da secretaria } & \text { In jail } \\ \text { Para dar depoimento } & \text { To testify } \\ \text { Daquilo que não sabia } & \text { About what he did not know } \\ \text { Camará } & \text { Comrade }\end{array}$

This text combines the beginning of the Paraguayan War ladainba with the story of Pedro Mineiro, but Caiçara replaces Pedro Mineiro's name with his own and adapts the outcome to his own needs. He is no longer killed, only jailed to testify what he did not know. Caiçara therefore establishes a direct link between the veterans of that war, the famous tough guy, and himself. He somehow becomes them or at least places himself in the direct continuation of these epic heroes. Anybody who has known Caiçara will easily confirm that he could do this because he was one of Salvador's last tough guys (at least in the old sense of the term). He was arrested many times for disorderly conduct during the street festivals or in the red-light districts of the port area. He even challenged Bimba in his academy and had his jaw broken by the inventor of the Regional style.

Yet modernization of capoeira meant that the practice was transferred from the streets into the academies where students paid monthly fees and trained in uniforms. Their mestres are no longer tough guys who were famous in street brawls, but professionals with a reputation to maintain. It is possible that for this reason the genre of stories about Besouro and Pedro Mineiro can no longer be continued, despite the continued acclaim of these famous capoeiristas. Contemporary entry or praise songs (canto de entrado or louvação) often begin by enumerating the generation of long dead mestres and then, as mentioned earlier in this chapter, continue to praise those who are present at the roda. Some new ladainhas are composed for the teacher or esteemed mestre. ${ }^{40} \mathrm{~A}$ number of mestres of the older generations such as Boca Rica continue to sing about their own life and experiences:
Boca Rica é um cara legal

Boca Rica is a nice guy

Joga sua Angola, toca muito berimbau He plays his Angola and berimbau

Boca Rica é Mestre de Capoeira

Vende tomate, cebola, lá na feira well

He sells tomato, onion at the market
And they do this regardless of the fact that their exploits are now of a quite different nature:

\author{
Mestre Boca Rica \\ Capoeira (Refrain) \\ Mestre Nobre de Valor \\ Foi dar curso em Los Angeles \\ Até a gringa chorou
}

\author{
Mestre Boca Rica \\ Capoeira (Refrain) \\ A noble and worthy master \\ He gave a workshop in Los Angeles \\ Even the gringa shed tears ${ }^{41}$
}

\section{Conclusion}

Even though there is a growing importance of the role of records and textbooks, capoeira lyrics still represent a prime example of oral transmission of traditions in the twenty-first century. Songs articulate and transmit the broader aspirations and worldviews of adepts and the wisdom of an older generation of mestres. At the same time they fulfill important functions within the specific dynamics of each game. Ladainhas, louvaçoes, and corridos performed in historic and contemporary rodas provide many examples of inventive bricolage, whereby sections of older songs are used to compose new ones to suit the singers' purposes. For that reason, songs from the public domain are not rigid restatements whose contents are rigidly fixed but instead they acquire new meanings with each performance. If the capoeira game constitutes a kind of dialogue between the movements of two capoeiristas, the lyrics help musicians to build up several other dialogues: one is with the players in the roda, another is with the audience around the circle, and a third one is among the musicians themselves. These dialogues are made of metaphysical proverbs, historical narratives of a glorious past, or ironic comments on a game. Verses entertain the audience, preserve capoeira history, provide models of behavior for younger generations, or maintain the rhythm and stamina of the game. The multitude of functions and crossreferences of the lyrics contribute toward the rich texture and the cultural 
density of a capoeira performance. As is true of the entire game, capoeira songs are a prime example of living traditions.

Adepts consider capoeira practice to be an emancipating practice in itself and thus the songs provide explanations and legitimacy for the game. If on the one hand the lyrics transmit historical experiences of slavery, emancipation, acts of heroism or pride in being African, Afro-Brazilian, or Brazilian, they also express an extremely dynamic relationship with the past. The past is always reinterpreted from the needs of the present and in that respect one cannot interpret capoeira lyrics as immutable historical documents. The evolution of lyrics on some core themes reflects developments that are taking place in Brazil's broader society (and increasingly elsewhere) including the ongoing struggle for emancipation from racial, class, or any other oppression. The reassessment of Abolition or Africa's contribution to Brazilian popular culture is articulated in these changes in capoeira lyrics that also provide an important vehicle through which perceptions are readjusted.

\section{Notes}

The author would like to thank Erna von der Walde and Florence Royer (Jurema) as well as the participants of the conferences "Literary Manifestations of the African Diaspora," University of Cape Coast, Cape Coast (Ghana) November 10-14, 2003, and "The Portuguese Atlantic: Africa, Brazil, and Cabo Verde," Mindelo, Cape Verde, July 7-9, 2005, for comments on earlier drafts of this paper.

1. In nineteenth-century and early-twentieth-century sources, practitioners are referred to as capoeiras, whereas contemporary adepts are now called capoeiristas.

2. The most detailed account of this period in Rio de Janeiro is provided by Carlos Eugênio Líbano Soares, A capoeira escrava e outras tradições rebeldes no Rio de Janeiro, 1808-1850 (Campinas: UNICAMP, 2001).

3. For a more detailed discussion of myths and fakes in capoeira history, see Luiz Renato Vieira and Matthias Röhrig Assunção, "Mitos, controvérsias e fatos. Construindo a história da capoeira," Estudos Afro-Asiáticos 34, (1998): 81-120.

4. Annibal Burlamaqui, Gymnastica Nacional (Capoeiragem) metbodizada $e$ regrada (Rio de Janeiro: n.e., 1928), 11-12.

5. See CD Essência. O berimbau e a voz do eterno Bimba (Salvador: Fundação Mestre Bimba, 2001), tracks 1-2.

6. Rego, Capoeira Angola 67: 106.

7. For further examples, see Lewis, Ring of Liberation, 163-167.

8. For a further discussion of capoeira as "verbal play" see Lewis, 162-187 and also Downey, "Incorporating," 127-141.

9. It is worth noting that some recent songs of known authorship seem also to have entered the public domain insofar as performers do not always recognize their authorship.

10. For Bahia, see Manuel Querino, A Babia de outrora (3rd ed., Salvador: Livraria Progresso Editora, 1946), 73; for Rio de Janeiro, see Carlos Eugênio Líbano Soares, A capoeira escrapa e outras tradifões rebeldes no Rio de Janeiro, 1808-1850 (Campinas: Editora da Unicamp, 2001), 124-33. 11. Elements of Arab civilization came to Brazil through both the Portuguese
and enslaved West African Muslims. The tambourine has been used since medieval times on the Iberian Peninsula.

12. Some U.S. scholars have attempted to interpret capoeira from an "Afrocentric" perspective, by reading what they consider "traditional" Central African meanings into the contemporary Brazilian game. For the most detailed attempt, see Desch-Obi, "Engolo." Interestingly enough, these interpretations cannot rely on any evidence from the "traditional" capoeira lyrics.

13. Lingua geral, derived from Tupiniquim and other Tupi languages, was the main vernacular used in colonial Brazil.

14. For more details, see Rego, Capoeira Angola, 126-141.

15. Quoted in Querino, A Babia, 76 and in Rego, Capoeira Angola.

16. Rego, Capoeira Angola 33: 94. I have not found any older mention of these lyrics, so it is possibly a relatively recent song. For an analysis of the role of dendê, see Raul Lody, Tem dendê, tem axé. Etnografia do dendezeiro (Rio de Janeiro: Pallas, 1992).

17. Rego, Capoeira Angola 62: 104.

18. Oscar Ribas, Dicionário de regionalismos angolanos (Matosinhos: Contemporânea, 1994), 2, 144; Wyatt MacGaffey, "Twins, Simbi Spirits, and Lwas in Kongo and Haiti," in Linda M. Heywood, ed. CentralAfricansand Cultural Transformations in the American Diaspora (Cambridge: CUP, 2002), 214, 223. In Angola, the gift the groom pays to the bride's family is called alembamento.

19. NB: Angoleiro refers to the practitioner of Angola in contrast to angolanos, the inhabitants of Angola.

20. See M. Boca Rica, CD A poesia de Boca Rica (Manaus: Cântaro Estúdio, ca. 2001 ), track 14 . One version of "Eu sou angoleiro" has already been recorded by Rego, Capoeira Angola 32: 93.

21. His manuscripts contain two versions of this ladainba, but without that verse about the African origins. See Vicente Ferreira Pastinha, "Manuscritos e desenhos de Mestre Pastinha" (Org. by Angelo Decanio Filho, Salvador: 1996), 46A, 60B. The added verse can be heard on M. Pastinha, Capoeira Angola (n.p., Fontana Stereo, 1969), track 1.

22. "Pastinha já foi a África, a mostrar capoeira do Brasil." M. Pastinha, CD Capoeira Angola (Fontana Stereo, 1969), track 2. I would like to thank M. Cobra Mansa for discussing these ladainhas with me.

23. M. João Grande, CD Capoeira Angola, New York: 2001, track 6. If not otherwise stated, all English versions of Brazilian songs are my translation.

24. Mestre Moraes, CD Brincando na Roda (Salvador: GCAP - Grupo Capoeira Angola Pelourinho, 2001), track 3.

25. M. Moraes, Brincando na Roda, track 7.

26. As translated by Downey, "Incorporating Capoeira," 91.

27. As sung by Alex Muniz on the CD João Pequeno de Pastinha (Salvador: WR Discos, 2000)

28. Figures from J.P. de Sousa, Escravidão ou morte. Os escravos brasileiros na Guerra do Paraguai (Rio de Janeiro: Mauad/ADESA, 1996), 89. Querino (A Babia, 188) claims as much as 18,725 Bahians fought in Paraguay. Oral tradition has it that slave capoeiras were already serving in a patriot battalion during the War of Independence, but no written evidence has yet been found to confirm it. See Daniel Coutinho, $O A B C$ da capoeira angola. Os manuscritos do Mestre Noronba (Brasilia: DEFER/GDF, 1993), 35. 
29. Querino, A Bahia, 78-80.

30. "Paranaê" probably refers to the Paraná river that runs from Brazil into Paraguay and forms part of the border between both countries.

31. CD-Mestre Traira: Capoeira da Bahia (São Paulo: Sonopress-Rimo, n.d.), track 1. This ladainba has many different versions, not all of them mentioning explicitly the Paraguay War. See also Rego, Capoeira Angola 60: 103, and 103: 117.

32. Rego, Capoeira Angola 78: 109.

33. See for instance M. Canjiquinha, Capoeira (São Paulo: Sonopress-Rimo Indústria e Comércio Fonográfica Ltda, 1986), track 18; M. Moraes, CD. Brincando na roda, track 8.

34. Newspapers also registered the case. See for instance Diário de Noticias (Salvador), March 3, 1916.

35. Coutinho, $O A B C, 24$. For another version see Rego, Capoeira Angola 126: 122. Pedro Mineiro also enjoyed the protection of the ex-governor J.J. Seabra. See Jair Moura, Mestre Bimba. A crônica da malandragem (Salvador: author's ed., 1991), 60 .

36. Coutinho, $O A B C, 41$.

37. CD Capoeira M. Waldemar \& M. Canjiquinha (São Paulo: Sonopress-Rimo Indústria e Comércio Fonográfica Ltda, 1986), track 14.

38. For a recent assessment of Pedro Mineiro based on new archival evidence, see Antonio Liberac Cardoso Simões Pires, "Escritos sobre a cultura afro-brasileira. A formação histórica da capoeira contemporânea, 1890-1950." PhD thesis in History, UNICAMP, Campinas, 2001.

39. M. Caiçara, LP Academia de Capoeira Angola de São Jorge dos Irmãos Unidos do Mestre Caiçara (São Bernardo do Campo/SP: Discos Copacabana, 1973), track 1. For the translation, see Capoeira Songbook for estrangeiros, (Washington, DC: International Capoeira Angola Foundation: n.d.), 4.

40. See for example, "Grande João Grande" by M. Moraes, Brincando na roda, track 6; "M. Waldemar da Liberade," by M. Luiz Renato (Grupo Beribazu), CD Músicas de Capoeira (Manaus: Microservice Tecnologia, n.d.), track 3; "Seu Pastinha mandou falar" by M. Pé de Chumbo, CD M. Pé de Chumbo e convidados, (Manaus: Sonopress, ca. 2002), track 2.

41. M. Boca Rica, CD $A$ poesia, tracks 2 and 3.

\section{Bibliography}

Burlamaqui, Annibal. 1928. Gymnastica Nacional (Capoeiragem) methodizada $e$ regrada. Rio de Janeiro.

Capoeira Songbook for estrangeiros. n.d. Washington, DC: International Capoeira Angola Foundation.

Coutinho, Daniel. 1993. O ABC da capoeira angola. Os manuscritos do Mestre Noronha. Brasília: DEFER/GDF.

Desch-Obi, Thomas J. 2000. "Engolo: Combat Traditions in African and African Diaspora History." PhD Dissertation in History, University of California, Los Angeles.

Downey, Greg. 1998. "Incorporating Capoeira: Phenomemology of a Movement Discipline." PhD Dissertation in Anthropology, University of Chicago.
Kubik, Gerhard. 1979. "Angolan Traits: Black Music, Games and Dances of Brazil. A Study of African Cultural Extension Overseas." Estudos de Antropologia 10. Lisbon: Junta de Investigações Científicas.

Lewis, J. Lowell. 1992. Ring of Liberation. Deceptive Discourse in Brazilian Capoeira. Chicago: University of Chicago Press.

Lody, Raul. 1992. Tem dendê, tem axe. Etnografia do dendezeiro. Rio de Janeiro: Pallas.

MacGaffey, Wyatt. 2002. "Twins, Simbi Spirits, and Lwas in Kongo and Haiti," in Linda M. Heywood, ed. Central Africans and Cultural Transformations in the American Diaspora. Cambridge: Cambridge University Press, pp.230-260.

Makuna, Kazadi wa. 2000. Contribuição Bantu na música popular brasileira: perspectivas etnomusicológicas. São Paulo: Terceira Margem.

Moura, Jair. 1991. Mestre Bimba. A crônica da malandragem. Author's ed.: Salvador.

Pires, Antonio Liberac Cardoso Simões. 2001. "Escritos sobre a cultura afro-brasileira. A formação histórica da capoeira contemporânea, 1890-1950." PhD thesis in History. Campinas: UNICAMP.

Querino, Manuel. 1946. A Bahia de outrora. 3rd ed. Salvador: Livraria Progresso Editora.

Rego, Waldeloir. 1968. Capoeira Angola. Ensaio sócio-etnográfico. Salvador: Itapuã. Risério, Antônio. 1995. Oriki Orixá. São Paulo: Perspectiva.

Soares, Carlos Eugênio Libano. 2002. A capoeira escrapa e outras tradições rebeldes no Rio de Janeiro, 1808-1850. Campinas: Editora da Unicamp. 